\title{
21618 慣性力発生装置を用いた振動キャンセルシステムの開発
}

Development of a New Active Vibration Canceling System Using Inertial Force Generators

\author{
○ 山下智之（東京農工大） 正 田川泰敬（東京農工大） \\ 正 田上将治（東京農工大）野川尚孝（東京農工大） \\ 洞宏一（特許機器）野口保行（特許機器）＼cjkstart加藤久雄（特許機器）
}

Tomoyuki YAMASHITA, Tokyo University of Agriculture and Technology,

2-24-16 Naka-cho, Koganei-shi, Tokyo 184-8588

Yasutaka TAGAWA, Masaharu TAGAMI, Naotaka NOGAWA, Tokyo University of Agriculture and Technology Hirokazu HORA, Yasuyuki NOGUCHI, Hisao KATO, TOKKYOKIKI CORPORATION

The control of vibration is important for high technology field such as semiconductor manufacturing. In this field, active vibration isolation device has achieved good performance to reduce vibration. But recently, stage device is bigger and stage movement is more quickly. Therefore the reaction force for vibration isolation is bigger and transmitted to the floor. In this study, in order to solve this problem, we developed an active vibration system using inertial force generators. Dual Model Matching control method is adopted for this system. We confirmed effectiveness of vibration isolation by experiment.

Keyword: Micro Vibration, Vibration Control, Dual Model Matching Control

\section{1.背景および目的}

半導体デバイスの製造は，十分な振動制御性能を確保する ことが求められている. 近年, 半導体の集積回路, 液晶基板 をつくる露光装置では, 半導体ウエハの高集積化により, 許 容できる振動は小さくなってきている. しかし, ウエ八, 液 晶基板の大型化によりそれらを移動させるステージも大型化 し，さらには高速化している．そのためステージ移動による 自己振動は大きくなってきている.

従来のアクティブ除振装置(1)でもステージ移動による振動 を㧕制できるが，振動が大きくなると，床一の制御反力も大 きくなる. そのため制御反力が床面に伝わり，同一床面に設 置された周辺機器にも影響を与えてしまう. そこで本研究で はステージ駆動による反力を内力としてキャンセルする振動 キャンセルシステムを提案した. 慣性力発生装置「キャンセ ラ」を用いステージ移動による振動を抑制することを目的と する.これにより, アクティブ除振装置のアクチュエータ発 生力が小さくなり, 床への振動伝播も小さくなる. キャンセ ラにはアクチュエータとしてリニアモータを利用し, 制御則 には Dual Model Matching 法を用いた. 本研究で提案した 振動キャンルシステムの有効性を実験により確認した。

2.キャンセルシステムの原理および実蜍装膡

本研究で提案するキャンセルシステムのモデルを Fig.1 に、 実験装置の外観を Fig.2 に示す。ステージ, 除振テーブル, 水平キャンセラ, 鉛直キャンセラ, 除振ユニットから構成さ れる. キャンセラとは慣性力発生装置のことである. ステー ジを駆動させると, 水平方向の反カとモーメントがテーブル に加わる. この水平方向の反力を打ち消すために水平キャン セラをステージと逆向きで同じ力で駆動させる. これで水平 方向の振動はキャンセルできる.さらにモーメントを打ち消 すために鉛直キャンセラを駆動させる. 各キャンセラの目標 加速度はステージ加速度によって決まり, ステージ加速度に 比例したものとなる.

3.キャンセラ単体の制御系設計

本実験に使用するキャンセラは Dual Model Matching 法
（DMM 法）により制御を行う. DMM 法による制御系のブロ ック線図を Fig.3に示す. DMM 法とは目標値 $\mathbf{r}$ から制御量 $\mathbf{y}$ 間の閉ループ伝達関数 $W_{x y}$ および外乱 $\mathrm{d}$ から制御量 $\mathrm{y}$ 間の閉 ループ伝達関数 Wdyまはノイズ $\mathrm{v}$ から制御量 $\mathrm{y}$ 間の閉ルー プ伝達関数 $W_{v y}$ を独立に設定し，それらの伝達関数を実現す る制御器を設計する手法である. Fig.3から

$$
\left\{\begin{array}{l}
W_{n y}=\left(1-P_{u y} C_{y u}\right)^{-1} P_{u y} C_{n u} \\
W_{v y}=\left(1-P_{u y} C_{y u}\right)^{-1} P_{u y} C_{y u} \\
W_{d y}=\left(1-P_{u y} C_{y u}\right)^{-1} P_{d y}
\end{array}\right.
$$

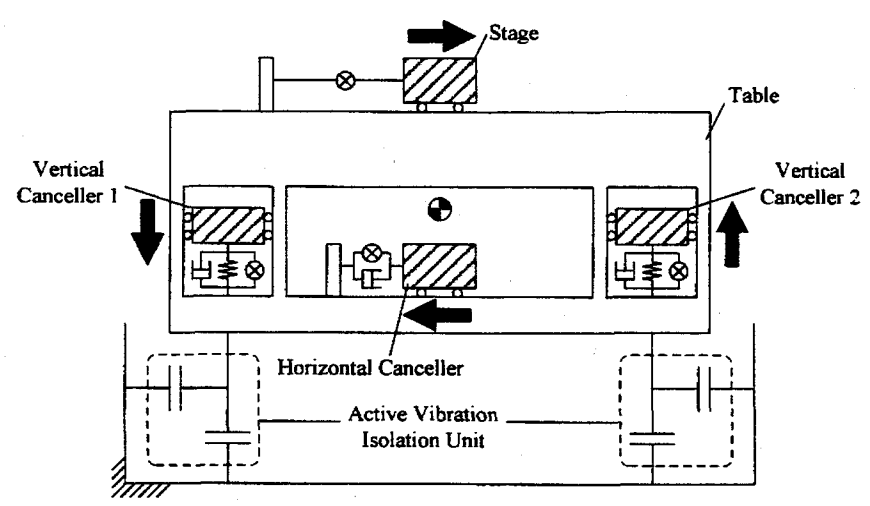

Fig.1 Model of Vibration canceling System

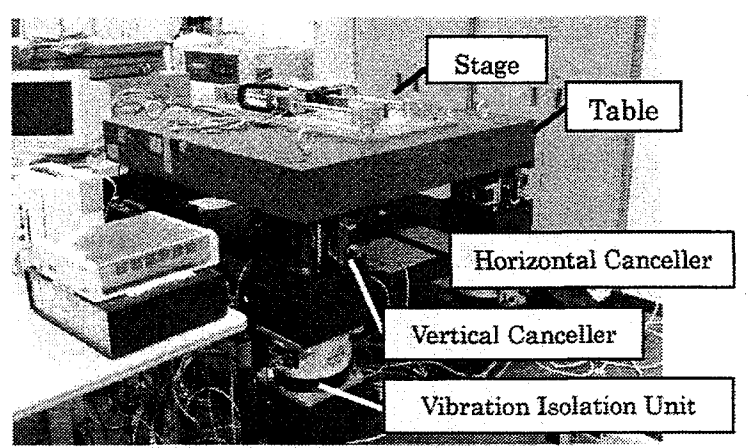

Fig.2 Photograph of vibration canceling system

日本機械学会関東支部第 13 期総会講演会講演論文集 ['07 - 3.16,17, 宇都宮市 ] 
となる。なお $P_{u y}, P_{d y}$ は $\mathrm{r}-\mathrm{y}$ 間および $\mathrm{d}-\mathrm{y}$ 間のプラントの伝 達関数で $C_{r u}, C_{y u}$ は $\mathrm{r} \cdot \mathrm{u}$ 間および $\mathrm{y} \cdot \mathrm{u}$ 間の制御器の伝達関数 である. 式(1)より制御器の伝達関数

$$
\left\{\begin{array}{l}
C_{r u}=P_{u y}^{-1} W_{r y}\left(1+W_{v y}\right)^{-1} \\
C_{y u}=P_{u y}{ }^{-1} W_{v y}\left(1+W_{v y}\right)^{-1}
\end{array}\right.
$$

が導かれる. つまり, DMM 制御器の伝達関数は $W_{x y}, W_{v y}$ を望みのものに設定することにより決定される．W $W_{\text {Vy }}$ は加速 度信号にノイズが多いことより 2 次のローパス効果を付加し た. $W_{x y}$ は DC カットと広帯域で追従させるためバンドバス 特性とした。これによりノイズを㧕え，かつ追従性をよくす ることが可能である。

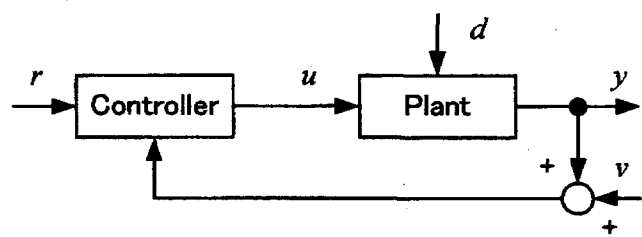

$\mathbf{r}$ : Desired Acc. $\mathbf{u}$ : Manipulated input

$\mathrm{d}:$ Disturbance Acc. $\mathrm{y}$ : Canceller Acc. $\mathrm{v}$ : Noise

Fig.3 Block diagram of DMM

\section{4.キャンセラ単体での実䮦}

鉛直，水平キャンセラに DMM 制御を適用し，キャンセラ 単体での実験を行った. 目標加速度からキャンセラマス加速 度の動特性を測定した．鉛直キャンセラの測定結果を Fig.4 に示す. DMM 制御を適用すると，プラントが持つ共振がな くなり，位相の遅れも改善できた. 水平キャンセラも同様の 結果となる.

\section{5.キャンセルシステム効果確認実倹}

実験装置全体の構成を Fig.5 に示す．各キャンセラの目標 加速度はステージ加速度から算出される. 各キャンセラには DMM 制御が適用される。

ステージを駆動させた時, テーブル上加速度と空気アクチ ユエータ内圧変動をキャンセラを使用した場合とそうでない

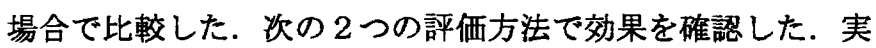
験結果を Fig.6，Fig.7 に示す.

\section{(1) 時間領域}

ステージを三角波で駆動する．テーブル加速度と床反力の 大きさを測定する. 振幅 $2 \mathrm{~V} て ゙ ~ 10 \mathrm{~Hz}$ の三角波を 2 秒おきにフ アンクションジェネレータで出力させ，これをステージ駆動 信号とした.

(2) 周波数領域

ステージをスイープサイン波で駆動する．ステージ加速度 からテーブル上加速度,床反力までの周波数特性を測定する. ステージ駆動信号は振幅 IV で $0.5 \mathrm{~Hz}$ から $300 \mathrm{~Hz}$ を $120 \mathrm{~s}$ でス イープするスイープサイン波である.

\section{6.まとめ}

・慣性力発生装置キャンセラを用いた振動キャンセルシステ 么を提案した。

・キャンセラに DMM 制御を適用し，良好な加速度追従性能 を得ることができた。

・実験によりキャンセルシステムの有效性を確認した。

\section{7.参考文献}

(1) 西山禎昌, 田川泰敬, 安田正志, 6 自由度微振動試験機の 制御に関する研究，日本機械学会論文集 Vol.66 No.643 Page.771-777, 2000
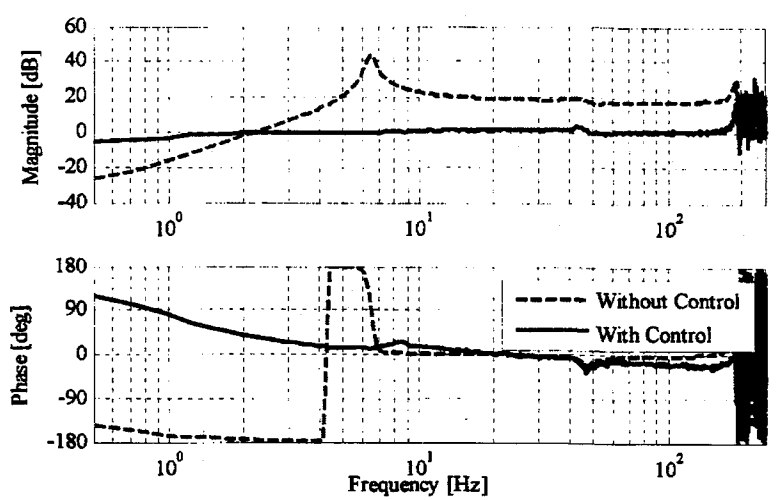

Fig.4 Frequency Response of a vertical canceller

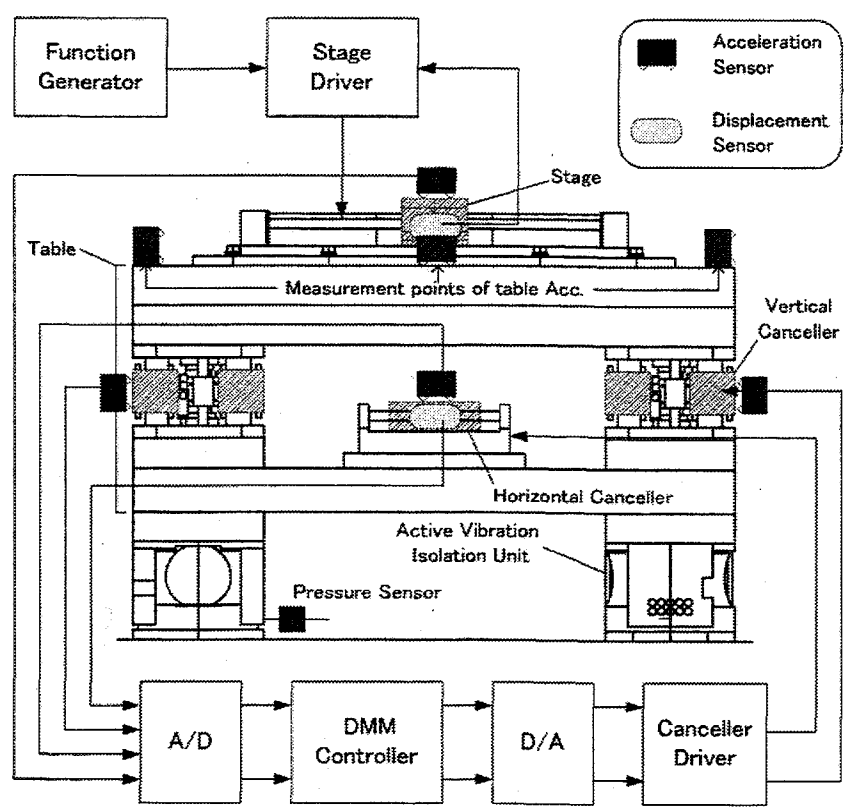

Fig.5 Structure of vibration canceling system

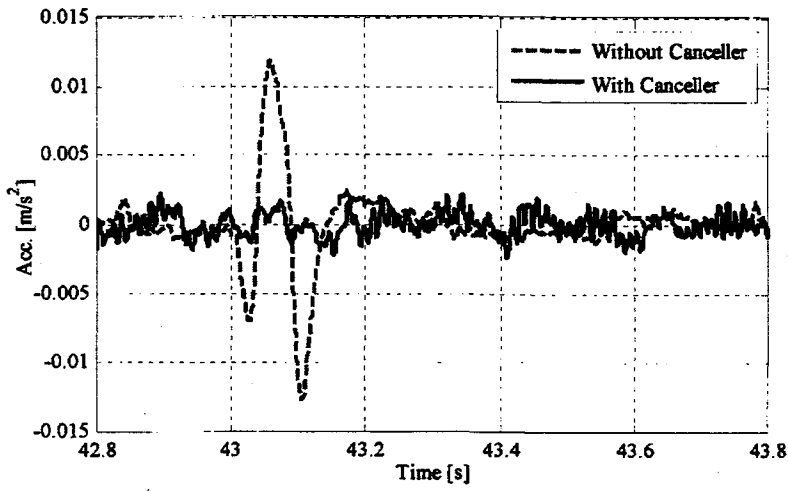

Fig.6 Horizontal acceleration of a table

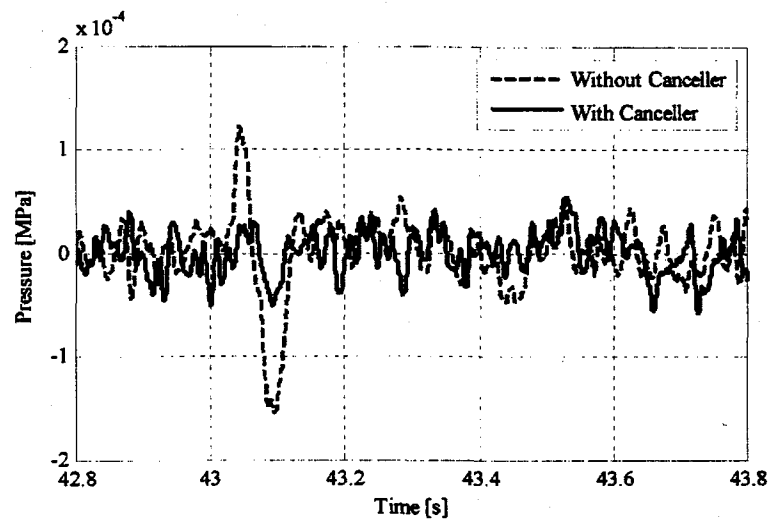

Fig.7 Internal pressure of an air spring 